\title{
Nástup do veřejné mateřské školy v České republice: sonda do adaptace rodiče
}

\author{
Eva M. Hejzlarová, Magdalena Mouralová, \\ Kateřina Konrádová \\ Univerzita Karlova, Fakulta sociálních věd
}

\begin{abstract}
Abstrakt: Proces adaptace ve vzdělávacím systému byl dosud v české akademické reflexi studován výhradně v souvislosti s adaptací dětí. Článek tematizuje adaptaci rodiče a dává ji do souvislosti s utvářejícím se vztahem mezi rodičem a školou. Teoreticky se stat' opírá o odbornou literaturu konceptualizující adaptaci, vztah rodiče a školy včetně partnerství a možné role rodiče. Empiricky staví na analýze deníkových záznamů 14 informantek, které mapují prvních 12 týdnů docházky jejich nejstaršího dítěte do veřejné mateřské školy v České republice. Analýza ukazuje, že s perspektivou rodiče proces adaptace $v$ mateřské škole př́liš nepočítá. Na ustavení role „rodiče dítěte $v$ mateřské škole“ má zásadní vliv průběh adaptace dítěte a dále požadavky, očekávání a podpora ze strany mateřské školy. Rodičovská role po období adaptace je typická relativně úzkým zájmem rodiče o jeho dítě, omezenou ochotou rodiče řešit s mateřskou školou své problémy či pochybnosti, minimalizací rodičovské iniciativy, spolehlivým plněním provozně-materiálních požadavků a základním uznáním prostředí mateřské školy i s jeho omezeními.
\end{abstract}

Klíčová slova: adaptace, přechodová událost, partnerství, mateřská škola, rodič, vztah rodiče a školy

\section{Transition from Home to Public Kindergarten in the Czech Republic: Insight into Parental Adaptation}

Abstract: Until now, the process of adaptation in the education system has been researched by Czech scholars exclusively in connection with the adaptation of children. This empirical study examines the adaptation of parents in relation to the formation of the relationship between them and their child's school. The theoretical framework of the study is based on literature conceptualizing adaptation, relationships between parents and schools, including the matter of partnership, and different roles of parents in school environments. Fourteen parents were instructed to write diary entries during the first twelve weeks of their eldest child's attendance at a public kindergarten in the Czech Republic. Analysis of the data shows that the parents' perspectives are not sufficiently considered in the process of adaptation in kindergarten. Still, the development of the child's adaptation, as well as the requirements, expectations and support received from the kindergarten, have a fundamental influence on the establishment of the parent's role in relation to their child's school. The parent's role in the course of the adaptation period is characterized by their interest in their child, their limited willingness to address their problems or their doubts regarding the school, minimization of their initiatives, their reliability in fulfilling operational and material requirements and their basic appreciation and acknowledgment of the school and its limitations.

Keywords: adaptation, transition, partnership, kindergarten, parent, parent-school relationship 
58 Nástup dítěte do mateřské školy (dále také „MŠ“) je pro řadu rodin v Česku významným milníkem. $V$ souvislosti s relativně dlouhou rodičovskou dovolenou (OECD, 2018), malou (finanční) dostupností zařízení péče o děti do tří let (Eurydice, 2017) a také pochybnostmi společnosti nad vhodností kolektivních zařízení pro děti raného věku (Hašková et al., 2012; Prokop, 2019, s. 83-90) jsou začátky docházky do MŠ emočně silným obdobím. Dítě se poprvé významně osamostatňuje a začíná trávit výraznou část dne mimo svoji rodinu, v důsledku čehož se dostává do nových situací a rolí - nástup do MŠ je tak jednou z prvních velkých přechodových událostí v jeho životě (Niesel \& Griebel, 2005; Vágnerová, 2012, s. 231). Navíc se vzhledem k poměrně vysoké účasti na předškolním vzdělávání a husté síti veřejných MŠ jedná také o událost široce sdílenou (MŠMT, 2020, s. 89-92).

Zároveň se $v$ tomto období rodina dostává ( $v$ př́padě nejstaršího dítěte poprvé) do kontaktu se vzdělávacím systémem. Rodič konfrontuje své představy o jeho fungování s „realitou“, testuje jeho prínosy, ale i očekávání a nároky, a směrem k systému se socializuje, tj. vytváří si k němu vztah a spoluutváří svou novou roli. Přestože se postupem času a vlivem různých okolností může role rodiče proměňovat, nelze tuto iniciační zkušenost opomenout. Může totiž mít vliv na to, jakým způsobem se bude rodič k systému vztahovat a chápat svou roli v dalších fázích vzdělávání svého dítěte (srov. Helus, 2014; Vágnerová, 2012).

Předškolní vzdělávání přitom představuje významné období ve vzdělávací dráze každého jedince. Kvalitní předškolní vzdělávání dokáže vyrovnávat nepřiznivé socioekonomické zázemí dítěte, jehož provázanost s volbou studijních trajektoriî a dosaženým vzděláním je zejména v České republice velmi silná (Matějů et al., 2010; Prokop \& Dvořák, 2019). Př́nosy raných intervencí pro jedince i společnost jsou výzkumně silně podloženy (Heckman et al., 2010; Melhuish et al., 2015); socioekonomický status rodiny, vztahy rodiny se školou a výsledky dítěte tak představují vzájemně provázané proměnné.

$Z$ těchto důvodů se chceme věnovat počátkům utváření prvního vztahu rodiče s veřejnou vzdělávací institucí, tj. rodiče, jehož nejstarší dítě nastupuje do veřejné MŠ. Jsme přesvědčeny, že zpracování tohoto tématu obohatí jak akademickou komunitu, tak praxi. Naší statí chceme přispět v nejširším slova smyslu do diskuse o předškolním vzdělávání, která se $v$ tuzemsku začíná více rozvíjet $\mathrm{v}$ posledních letech, především $\checkmark$ souvislosti s novými opatřeními, jež jsou zaváděna či diskutována (např. povinný poslední ročník $v M S)^{1}$, a přispět do debaty o vztazích mezi rodinou a školou $v$ Česku (Majerčíková, 2011, 2015; Pulišová, 2016; Rabušicová, 2004; Rabušicová et al., 2003; Rabušicová et al., 2004; Rabušicová \& Emmerová, 2003; Simonová, 2017; Šed’ová, 2009; Štech, 2004; Viktorová, 2020; Viktorová \& Štech, 2010). Náš přispěvek je originální tím, že prezentuje adaptaci rodiče s využitím jeho vlastní perspektivy, což není obvyklé ani v mezinárodním kontextu. Hlouběji se pak chceme věnovat rodičovské adaptaci jako procesu, v němž se vztahy mezi rodinou a školou utvářejí

V posledních letech tak byla předškolnímu vzdělávání např. věnována dvě monotematická čísla odborných časopisů - Orbis scholae (Straková \& Simonová, 2017) a Pedagogická orientace (Kropáčková \& Janík, 2014). 
a usazují. Ten je v české akademické reflexi na rozdíl od zahraničních tradic (zejména té skandinávské - srov. Karlsson \& Perälä-Littunen, 2017; Markström \& Simonsson, 2017) opomenut téměř zcela.

Naše cíle jsou konkrétně tyto: 1) zvýznamnit proces adaptace rodiče pro utváření vztahů mezi rodičem a školou, 2) popsat proces adaptace rodiče $z$ jeho perspektivy a zasadit ho do kontextu utváření vztahů mezi rodičem a školou v Česku, 3) diskutovat implikace našich zjištění pro vzdělávací politiku. Empiricky přitom čerpáme z deníkových záznamů, které si 14 informantek vedlo v prvních 12 týdnech docházky jejich nejstaršího dítěte do veřejné $M \check{\text { Š. }}$

\section{Teoretické ukotvení a přehled stavu poznání}

Nástup dítěte do mateřské školy patří mezi přechodové události, což jsou významné body $v$ životě jednotlivce, které se pojí se změnou aktivit, statusu, role, vztahů, užívaného prostoru a praktik (srov. Havlík \& Kot’a, 2007, s. 49; Niesel \& Griebel, 2005)². V kontextu vzdělávacího systému jsou typickými přechodovými událostmi nástup do školy, přechod mezi vzdělávacími stupni či ukončení studia; nejvíce pozornosti se dostává začátku povinné školní docházky, a to jak v kontextu mezinárod-ním (např. Chan, 2012; Petriwskyj et al., 2005; Yngvesson \& Garvis, 2019), tak českém (např. Lietavcová et al., 2018; Šulová, 2016). Najdeme i studie zaměřené na nástup do institucí předškolního vzdělávání (např. Eisenhower et al., 2016; Fails Nelson, 2004; McIntyre et al., 2007; Rimm-Kaufman et al., 2000; Rous et al., 2010).

Vyrovnat se s životními změnami spojenými s přechodovou událostí bývá pro jedince náročné a trvá delší čas. Anglický termín transition se proto používá jak pro samotnou událost, konkrétní bod $v$ životě, tak pro delší období, které tomuto bodu přiléhá, ale také pro proces vypořádávání se změnou (Petriwskyj et al., 2005; Vogler et al., 2008). $V$ textu tyto významy terminologicky odlišujeme, o nástupu do MŠ píšeme jako o přechodové události, o době po nástupu jako o období adaptace a o procesu vypořádávání se s novou situací jako o procesu adaptace. Proces adaptace, na který se $v$ našem textu soustředíme primárně, pak považujeme za specifický typ socializace, která zahrnuje tři vrstvy: (a) přizpůsobování se požadavkům významných druhých, (b) zvnitřnění norem a hodnot druhých, (c) relativně svébytnou konstrukci jednání jako odpověd' na sociální situace (Havlík \& Kot’a, 2007, s. 47). Za výsledek procesu adaptace tak lze považovat víceméně stabilní stav, kdy adaptovaný jedinec rozumí požadavkům okolí, je s novou situací srovnaný, našel si v ní svou pozici a tato pozice je také jeho okolím akceptována, jinými slovy tedy přijímá a naplňuje novou sociální roli.

Nástup do MŠ představuje $v$ české společnosti výraznou sdílenou přechodovou událost. Ta přichází nejčastěji ve věku 3-4 let a znamená kulturní změnu, kdy dítě

2 V česky psané psychologické a pedagogické literatuře se setkáme též s termínem zlomová událost (např. Havlík \& Kot’a, 2007; Helus, 2014), ve stejném významu se (obdobně jako anglické transition) uživá i termín přechod (např. Vágnerová, 2012). 
60 vstupuje do nového prostředí mimo domov, je nuceno navazovat nové kontakty a vytvářet velké množství nových vztahů. Na dítě jsou kladena nová očekávání (např. sebeobsluha, zvládnutí odloučení od rodiny, komunikace s neznámými lidmi), setkává se s novými pravidly a činnostmi (srov. OECD, 2017; Vágnerová, 2012). Nástup do MŠ představuje typický vertikální přechod (Vogler et al., 2008), kdy se zvyšuje společenský status - začít chodit do MŠ je vnímáno jako postup, ale i jako závazek.

Nástup do MŠ je přechodovou událostí pro celou rodinu. Nieselová a Griebel (2005) v této souvislosti mluví o rodinném přechodu (family transition). Samotná situace předání dítěte do instituce a zanechání ho $v$ ní samotného je emocionálně náročná pro všechny zúčastněné, tedy i pro rodiče (Majerčíková, 2015, s. 33-34; Markström \& Simonsson, 2017, s. 179). V prípadě, kdy do MŠ nastupuje první dítě $v$ rodině, vstupuje i rodič do nové role „rodiče dítěte $v$ MŠ“, která zahrnuje nové vztahy, normy a očekávání, na něž se potřebuje adaptovat.

Na konkrétní podobu adaptace dítěte a rodiče má vliv řada faktorů ze strany instituce, dítěte $i$ jeho rodiny (Kot'átková, 2014, s. 93-100). Průběh adaptace po jedné přechodové události přitom ovlivňuje adaptaci při dalších přechodech podobného typu, v našem př́ípadě např. při vstupu do základní školy (Niesel \& Griebel, 2005; srov. OECD, 2017, s. 17). I proto důležitost adaptačního procesu v MŠ reflektují nejen odborné zdroje, ale i veřejněpolitické dokumenty (např. ČŠI, 2020; Kot’átková, 2014; Majerčíková, 2015; MŠMT, 2018; OECD, 2017; Syslová, 2013). Např́klad dle Rámcového vzdělávacího programu pro předškolní vzdělání by MŠ měla dětem zajistit „individuálně přizpůsobený adaptační režim“ (MŠMT, 2018, s. 33) a je povinností učitelů $M S ̌$ „umožnit rodičům aktivně se podílet na adaptačním procesu“ (MŠMT, 2018, s. 46).

Stran adaptace dítěte a její důležitosti má tedy odborná veřejnost jasno, ovšem význam adaptace rodiče (zejména dlouhodobější efekty různých typů adaptace rodiče na prostředí školy či na vzdělávací výsledky dítěte) je méně prozkoumaný i proto, že rodič není přímou cílovou populací vzdělávací politiky. Existuje relativně podrobná představa, jaké jsou výsledky rodičovských adaptací. Hanafinová a Lynchová (2002, s. 37) vyjmenovávají množství rolí, které mohou rodiče zastávat vzhledem ke škole (obhájce dítěte, zákazník, podporovatel, partner, spolupracovník, řešitel problémů i problém samotný, ale také třeba učitelobijec či policista). V české literatuře jsou většinou rozlišovány čtyři základní varianty role rodičů ve vztahu ke škole: rodič jako klient, partner, občan nebo problém (Rabušicová et al., 2003, 2004; Rabušicová \& Emmerová, 2003), které se liší typem a intenzitou interakcí i vzájemnými očekáváními.

Přímo vztahu mezi rodiči a mateřskou školou, dokonce i jeho vzniku věnuje pozornost Majerčíková (2015, s. 33-34), která upozorňuje, že rodiče do MŠ vstupují s vysokým zájmem o dění v MŠ a jsou nastaveni na spolupráci s MŠ, protože ji vnímají jako výhodnou pro své dítě, jemuž chtějí ulehčit adaptaci a pobyt v MŠ. Pro rozvinutí spolupráce je pak užitečná vysoká frekvence interakcí mezi personálem MŠ a rodiči při každodenním předávání dítěte; přesto se z různých důvodů partnerské vztahy ustavit nedaří (Majerčíková, 2015, s. 41). 
Zde je patrné, že teoretický a analytický koncept plynule přechází do konceptu hodnotového, kdy je partnerství bráno nejen jako jedna z možných podob vztahu mezi rodinou a školou, ale je považováno za vztah žádoucí, prospěšnější než jiné varianty pro rozvoj dítěte (srov. Markström \& Simonsson, 2017; Šed’ová, 2009). Partnerský vztah je přitom takový poměr, v němž je oběma stranám přiznáván význam pro rozvoj dítěte (Rabušicová et al., 2004); vztah mezi nimi by měl být proto rovnoprávný, nebot' sdílejí odpovědnost za blaho dítěte (Karlsson \& Perälä-Littunen, 2017). Kromě sdílení moci, odpovědnosti a cílů by partnerství mělo představovat „zodpovědný dialog zahrnující vzájemné naslouchání a vưli ke kompromisům a závazek ke společnému jednání“ (Bastiani 1993, cit. podle Šed’ová, 2009, s. 26). Vzdělávací instituce tedy mají usilovat o partnerství s rodiči tak, aby v jejich vztahu panovaly „oboustranná důvěra a otevřenost, vstřícnost, porozumění, respekt a ochota spolupracovat“ (MŠMT, 2018, s. 34; srov. Goshen, 2016). Reálný obsah konceptu partnerství v českém kontextu nejdetailněji prokresluje Šed'ová (2009), která zkoumá fungující vztahy mezi učitelkami prvního stupně a rodiči, kteří jsou učitelkami označováni jako spolupracující. Z její analýzy vystupují rodiče, již dobře odhadují i implicitní očekávání učitelek a snaží se jednat v souladu s nimi. Součástí tohoto partnerství je nejenom plnění požadavků, ale i držení odstupu, kdy rodiče sice aktivně demonstrují zájem, ale se svou aktivitou se přehnaně nevnucují. Aby neobtěžovali, snaží se místo přímé komunikace jít cestou neformálních, ne př́liš extenzivních kontaktů (např. „náhodných“ rozhovorů při vyzvedávání dětí). I když mezi rodiči a učitelkami dochází k dialogu a spolupráci, Šed’ová jejich vztah vykresluje jako asymetrický. Rodiče se na základě citlivého čtení představ učitelky, mezi které patří projevovaný, ale ne nijak urputný zájem o dítě nebo iniciativa „v mezích“, usazují v tzv. tichém partnerství, ve kterém se jim daří být „dobrými rodiči“ pro učitelky i naplňovat zájmy svých dětí. Podoba tohoto partnerství se nicméně značně liší od ideálu vymezeného výše.

Komplementární ke studii Šed'ové je výzkum Pulišové (2016), která se zaměřila na nefungující vztahy mezi rodičem a školou, přesněji na rodiče, kteří jsou učiteli vnímáni jako problém. Pulišová identifikuje tři typy „špatných rodičů“, jak je vnímají učitelé: pasivní, hlasitě nespokojené a tiše nespokojené. Jedná se přitom spíše o typy jednání, které mohou představovat i strategie, mezi nimiž rodiče přecházejí. Autorka takto popisuje trajektorii od hlasité nespokojenosti k tiché nespokojenosti a následnému opuštění školy bez vysvětlení. Pulišová tak zpochybňuje ideál partnerství a upozorňuje, že v českých podmínkách na něj není většina učitelů připravena. Velké angažmá rodičů je učiteli vnímáno jako ohrožující nebo přinejmenším obtěžující, což přijímá i řada rodičủ (srov. Šed'ová, 2009).

I řada dalších autorů upozorňuje, že k plnohodnotnému a rovnocennému partnerství mezi rodinou a školou často nedochází (Majerčíková, 2015; Pecháčková, 2014; Pulišová, 2016; Simonová et al., 2017; Štech, 2004), nebot' pozice obou stran jsou nevyvážené, at' už z důvodu rozdílné odbornosti (Karila, 2012), nebo rozdílné moci (Markström \& Simonsson, 2017). Ochota a připravenost k partnerství jsou rovněž determinovány kulturně a sociálně a uskutečňují se jen s některými skupinami rodičů (Hornby \& Lafaele, 2011; Katrňák, 2004; Majerčíková, 2015; Noel, 2008; Van Laere 
62 et al., 2018). Řada učitelů, ale i rodičů o takový vztah nestojí. Modelu partnerství odpovídá představa sdíleného cíle rodičů a učitelů. Ten sice většinou existuje v obecné rovině - zajistit, aby se dítě zdárně rozvíjelo, nijak netrpělo a bylo spokojené -, ale konkrétní operativní cíle a jejich hierarchie už bývají odlišné (Markström \& Simonsson, 2017, s. 180). Pro učitele je např. klíčové, aby se dítě začlenilo a nenabourávalo normy skupiny, pro rodiče, aby se dítěti dobře dařilo. Majerčíková (2015) upozorňuje ještě na další rizika úzké spolupráce rodiny a školy, jako jsou ohrožení zdravé socializace dítěte splynutím různých sociálních rolí či oslabení autonomie učitele, které podlamuje důvěru mezi rodinou a školou.

$\checkmark$ perspektivě všech těchto poznatků je tedy mimořádně zajímavé zkoumat období, kdy se vztah mezi rodinou a školou utváří. Markströmová a Simonssonová (2017) např. ukazují, jak švédští předškolní učitelé v průběhu adaptace vědomě formuji rodiče a učí je být „dobrými rodiči předškolního dítěte“, což v př́padě Švédska obnáši přiměřenou aktivitu, flexibilitu a samoregulaci. Formování vztahů mezi rodiči a školou na úrovni předškolního vzdělávání však stojí stranou české odborné diskuse (srov. Syslová \& Najvarová, 2012). Vztah mezi rodinou a školou je typicky zkoumán společně na úrovni preprimárního a primárního vzdělávání (Majerčíková, 2011, 2015; Rabušicová, 2004; Rabušicová et al., 2003; Šmelová, 2005; Štech, 2004; Trnková \& Čiháček, 2003); vztahy výlučně na úrovni MŠ se pak zabývají Burkovičová (2018), Pelikánová (2018), Provázková Stolinská a Rašková (2015) či Konrádová (2017), ovšem bez toho, aby se soustředily na okolnosti jejich vzniku.

Práce zaměřené na proces adaptace při nástupu do MŠ se zase nevěnují vztahům mezi rodiči, přestože je konstatována důležitost adaptačního procesu i „,pro vytvoření vztahu mezi rodičem a učitelem“ (Vyroubalová, 2015, s. 6). Adaptační proces je nahlížen téměř výhradně z pohledu profesionálů - učitelek a ředitelek MŠ (např. Lietavcová et al., 2018; Vyroubalová, 2015) - a soustředí se na adaptaci dítěte. Rodičovská perspektiva je zahrnuta jen výjimečně (srov. Burkovičová, 2018; Majerčíková \& Rebendová, 2016; Vyroubalová, 2015), a to opět v podobě reflexe adaptace dítěte nebo podpory při adaptaci.

$\checkmark$ zahraniční literatuře je partnerství mezi rodinou a MŠ i jeho ustavování v prvních měsících po nástupu dítěte do předškolní instituce věnována o něco větší výzkumná pozornost, zejména $v$ severských zemích, kde mají předškolní vzdělávání a péče vysokou společenskou podporu a dlouhou tradici (srov. Karila, 2012; Karlsson \& Perälä-Littunen, 2017). Vedle výzkumů zaměřených primárně na dítě a jeho adaptaci, pro jejiž úspěch je důležitá i spolupráce s rodiči (např. Månsson, 2011; Markström, 2010; Rous et al., 2010), najdeme i stati zacílené přímo na adaptaci rodičů do nové role a budování důvěry mezi rodinou a vzdělávací institucí (Alasuutari, 2010; Fails Nelson, 2004; Hedlin, 2019; Markström \& Simonsson, 2017; Simonsson, 2018; Vuorinen, 2018). I zde nicméně výrazně převládá perspektiva profesionálů-pedagogů. Rodičovský pohled zachycuje Vuorinenová (2018), která zkoumá strategie rodičů při adaptaci a identifikuje čtyři různé př́stupy $\mathrm{k}$ předškolnímu zařízení: (a) oceňování zvolené instituce, (b) snaha o změny $v$ rámci instituce, (c) smiření se se situací v předškolním zařízení (i když není zcela dle rodičovských představ), 
(d) opuštění konkrétního zařízení a nástup do jiného (Vuorinen, 2018, s. 205). Rodiče přitom mezi těmito př́stupy přepínají. Mohou se např. snažit o změnu, ale nejsou-li úspěšní, mohou rezignovat a smírit se, či naopak MŠ opustit. To koresponduje s trajektoriemi, jež na úrovni základní školy popsala Pulišová (2016).

\section{Data a metody}

Hlavním zdrojem dat pro zkoumání procesu adaptace a utváření rodičovské role byly deníkové záznamy, které si po dobu 12 týdnů vedly informantky, jejichž nejstarší dítě poprvé nastoupilo do veřejné MŠ. Časový úsek 12 týdnů byl zvolen jako dostatečně dlouhý, aby s rezervou pokryl nejdynamičtější část adaptačního procesu (srov. Kot'átková, 2014, s. 96-97; Šulová, 2016) a zároveň bylo pro informantky reálné si po danou dobu zápisky vést. Impulzem ke sběru dat byla přitom osobní zkušenost dvou členek týmu z docházky jejich dětí do veřejné MŠ. ${ }^{3}$

Do výzkumu se zapojilo 14 informantek, které byly rekrutovány přes osobní kontakty (výzvu na Facebooku) jedné z výzkumnic (se šesti z nich byla výzkumnice $\checkmark$ kontaktu již před zahájením výzkumu, zbývajících osm bylo osloveno zprostředkovaně). $V$ této výzvě byl formulován požadavek psát si po dobu tří měsícủ deník a být ochotný následně absolvovat výzkumný rozhovor a s přibližně půlročním odstupem další; s účastí na výzkumu byla spojena symbolická odměna. Lze předpokládat, že tento způsob výběru ovlivnil charakteristiky informantek $v$ tom smyslu, že $k$ účasti byly ochotnější ženy, a to spiše ty, pro které je rodičovství relativně prožívanějším tématem a které mají sociální a kulturní kapitál pro psaní tohoto typu záznamu a k účasti na dalších aktivitách. Závěry, které v tomto článku vyvozujeme, mají tedy vinou těchto limitů omezenou platnost. Vzorek zahrnuje zkušenosti informantek s ukončeným středoškolským (tj. středním vzděláním s maturitní zkouškou) nebo vysokoškolským vzděláním z velkých i menších měst a obcí České republiky s 13 veřejnými MŠ (a posléze s dvěma soukromými). Bližší informace o informantkách a mateřských školách, které navštěvovaly jejich děti, jsou v tabulce 1.

Adjektivum deníkový v souvislosti se zápisy informantek používáme, přestože se v př̌sném slova smyslu o deníky nejedná. Záznamy vznikaly „na zakázku“ výzkumnic a s vědomím, že budou čteny druhou osobou. I přesto splňují některé podstatné parametry deníků jako kvalitativních dat využitelných pro sociálněvědní výzkum (srov. Alaszewski, 2006): obecné zadání zapisovat to, co informantka v daném období řešila a prožívala $v$ souvislosti s nástupem svého dítěte do $M S ̌$, jí poskytlo poměrně velkou svobodu psát o všem, co považuje za podstatné, a to svými slovy a v rozsahu, pro jaký se sama rozhodne. $V$ případě některých informantek šlo o několik vět ke každému týdnu (a ne vždy byly popsány všechny týdny), u jiných jsme měly k dispozici

Jsme si vědomy toho, že osobní rodičovská zkušenost může ovlivňovat naše čtení dat. Riziko je zmírněno časovým odstupem a týmovou prací, kdy různé členky týmu mají různé zkušenosti s předškolním vzděláváním, a to nejen v roli rodičovské, ale též výzkumné, učitelské, průvodcovské. 
64 Tabulka 1 Charakteristiky informantek a mateřských škol

\begin{tabular}{|c|c|c|c|c|c|}
\hline & $\begin{array}{l}\text { Jméno } \\
\text { v článku }\end{array}$ & Vzdělání & $\begin{array}{l}\text { Počet dětí } \\
\text { a jména }\end{array}$ & Typ mateřské školy & Poznámky \\
\hline 1 & Adéla & VŠ & 1 (Anna) & waldorfská MŠ & $\begin{array}{l}\text { samoživitelka; dítě před } \\
\text { nástupem do veřejné MŠ } \\
\text { navštěvovalo dětskou } \\
\text { skupinu* }\end{array}$ \\
\hline
\end{tabular}

\begin{tabular}{|c|c|c|c|c|c|}
\hline 2 & Blanka & VŠ & 2 (Ben) & standardní MŠ (dvě třídy) & \\
\hline 3 & Dominika & VŠ & 1 (Dan) & $\begin{array}{l}\text { standardní MŠ (pět tříd); } \\
\text { poté přestup do firemní } \\
\text { MŠ }\end{array}$ & \\
\hline 4 & Eliška & vš & 2 (Eva) & waldorfská MŠ & \\
\hline 5 & Irena & SŠ & 1 (Ivo) & standardní MŠ (osm tříd) & \\
\hline 6 & Jitka & VŠ & $\begin{array}{l}\text { 2/dvojčata } \\
\text { (Jan a Jiří) }\end{array}$ & standardní MŠ (dvě třídy) & \\
\hline 7 & Kristýna & VŠ & 2 (Kát’a) & standardní MŠ (pět tříd) & \\
\hline 8 & Lenka & VŠ & 2 (Lea) & standardní MŠ (čtyři třídy) & \\
\hline 9 & Monika & VŠ & 2 (Mia) & $\begin{array}{l}\text { standardní MŠ (osm tříd); } \\
\text { poté kombinace s lesním } \\
\text { klubem }\end{array}$ & $\begin{array}{l}\text { dítě před nástupem } \\
\text { do veřejné MŠ } \\
\text { navštěvovalo lesní klub* }\end{array}$ \\
\hline 10 & Nikola & VŠ & 2 (Nina) & standardní MŠ (sedm tříd) & $\begin{array}{l}\text { dítě před nástupem } \\
\text { do veřejné MŠ } \\
\text { navštěvovalo dětskou } \\
\text { skupinu* }\end{array}$ \\
\hline
\end{tabular}

\begin{tabular}{llllll}
\hline 11 & Pavlína & SŠ & 1 (Petr) & standardní MŠ (dvě třídy) & \\
\hline 12 & Romana & VŠ & 2 (Radek) & standardní MŠ (čtyři třídy) & \\
\hline 13 & Simona & VŠ & $2($ Sam) & $\begin{array}{l}\text { standardní MŠ (čtyři } \\
\text { třídy); poté přestup } \\
\text { do jiné standardní MŠ } \\
\text { (čtyři tř́dy) }\end{array}$ & $\begin{array}{l}\text { dítě před nástupem do } \\
\text { veřejné MŠ navštěvovalo } \\
\text { dětskou skupinu* }\end{array}$ \\
\hline
\end{tabular}

14 Věra SŠ 2 (Vít) standardní MŠ (čtyři třídy)

Poznámka: * Označení „lesní klub“ či „dětská skupina“ odkazuje k právnímu statusu zařízení, které dítě navštěvovalo. $V$ promluvách informantek však typicky zaznívají neformálnější označení, obvykle se jedná pouze o pojmenování „školka“.

až 17 normostran textu. Další podstatnou výhodou těchto záznamů je také relativní drobnokresba a zachycení aktuálních situací a nálad, které mohou být s odstupem i jen několika měsíců překryty aktuálnějšími či silnějšími podněty, nebo dokonce zapomenuty; to činí deníky výborným zdrojem dat právě pro zachycení období adaptace po přechodové události. Zjevnou nevýhodou těchto dat je zároveň jejich těžiště ve výsostně subjektivním aktuálním prožívání - situace, na které informantky odkazují, se mohly klidně odehrát jinak a jistě měly další kontext, který by stavěl MŠ 
do jiného světla. Tato jednostrannost může dráždit, ale zároveň představuje syrový obraz prožívání „novými“ rodiči v MŠ, který si zaslouží reflexi. Smyslem naší stati totiž není vyvolat kontroverzi, ale otevřít diskusi vyložením karet. Deníkové záznamy pocházejí z období zárí až listopad 2014 ( $v$ jednom príípadě, kdy došlo $k$ pozdějšímu nástupu do MŠ, pak zachycují období říjen 2014 až leden 2015). Pro větší porozumění kontextu jsme četly také následné rozhovory - toto čtení mělo nicméně triangulační funkci, s rozhovory $v$ této stati nepracujeme.

Před stanovením výzkumných otázek jsme si záznamy opakovaně četly, diskutovaly jsme o tématech, která se nám jevila jako podstatná, a zvědomovaly jsme si naše osobní zkušenosti (př́nosem bylo, že jedna členka týmu nemá s MŠ bezprostřední rodičovskou zkušenost). Posléze jsme studovaly odbornou literaturu týkající se adaptace ve vzdělávacím systému a MŠ i vztahů mezi rodinou a vzdělávacími institucemi. Následně jsme formulovaly dvě výzkumné otázky, které nás při analýze vedly: Jaké byly charakteristiky procesu adaptace daných informantek - středostavovských matek - v průběhu prvních 12 týdnů docházky jejich nejstaršího dítěte do veřejné $M S ̌$ ? Jaké komponenty má nová role rodiče dítěte ve veřejné $M S ̌$ (tj. jaký je výsledek adaptace informantek)? Při analýze jsme využily postupů otevřeného kódování a vzniklé kódy jsme axiálně kategorizovaly do paradigmatického modelu. Vzhledem k tomu, že jde o první text zabývající se tímto tématem, rozhodly jsme se dát větší prostor deskripci, která umožňuje představit větší množství relevantních subtémat na úkor hloubky. Finální text jsme rozeslaly všem informantkám a požádaly je o účastnickou validizaci - zpětnou vazbu jsme získaly od šesti z nich, ve všech prípadech přitom informantky s našimi interpretacemi souhlasily.

\section{Zjištění}

Chceme-li co nejvýstižněji popsat proces adaptace rodiče, musíme se nejprve zaměřit na vykreslení jeho situace a toho, jaké své potřeby $v$ reakci na přechodovou událost formuluje a jak se $s$ přechodovou událostí v podobě nástupu dítěte do $M \check{S}$ vyrovnává. V další části představíme rodičovské čtení požadavků ze strany MŠ, které považujeme vedle zohledňování potřeb dítěte za stěžejní. Tyto požadavky mohou směřovat nejen $\mathrm{k}$ cíli adaptace, tj. $\mathrm{k}$ formování role rodiče tak, jak ji MŠ (velmi pravděpodobně nevědomě) chce mít, ale $i \mathrm{k}$ podpoře rodiče $v$ jeho adaptaci na přechodovou událost. Tento podpůrný element není v konceptualizaci adaptace, ze které jsme vycházely (srov. Havlík \& Kot’a, 2007, s. 47), př́liš patrný, považujeme nicméně za vhodné tento rys zvýraznit, protože naše data na něj odkazují. Předesíláme rovněž, že zejména $v$ této části jsme si vědomy omezení našeho datasetu, ve kterém je př́tomna pouze rodičovská perspektiva, jež může některé typy požadavků hypertrofovat a jiné třeba i přehlédnout. $V$ poslední části sledujeme, jakým způsobem probíhá zvnitřnění norem a hodnot $a v$ jakou odpověd' $v$ podobě role rodičovská adaptace ústí. 
Nástup do MŠ je přechodovou událostí pro dítě, rodiče i celou rodinu. Deníky psané našimi informantkami zachycují celou škálu pocitů a prožitků, které rodiče zažívají v prvních týdnech a měsících docházky dítěte do $M S ̌$, kdy se na novou situaci dítě a rodič adaptují. Rodiče se na novou etapu $v$ životě rodiny těší, ale mají z ní též obavy. $V$ průběhu adaptačního období popisují situace radosti i smutku, úlevu, stesk, zklamání či naštvání, hrdost i odhodlání. Leitmotivem deníkových zápisků je nicméně pocit nejistoty.

Ten je průvodním jevem jakékoli přechodové události, která vždy znamená životní změnu (srov. Niesel \& Griebel, 2005). V př́padě nástupu dítěte do MŠ ale rodičovská nejistota vychází též ze skutečnosti, že do MŠ nenastupuje rodič, ale jeho dítě. U řady situací je rodič jen vzdáleným pozorovatelem (srov. Vuorinen, 2018), u mnoha vůbec není prítomen a má o nich jen zprostředkované informace. Uspořádání nástupu do MŠ ani celkové fungování MŠ nejsou v režii rodičů, kteří nemají kontrolu nad pravidly a aktivitami, a jejich vliv je zde jen velmi omezený. Zároveň je ale rodič ve věci silně angažovaný, jako zákonný zástupce má potřebu (i povinnost) zajišt’ovat blaho svého dítěte, které se vzhledem k nízkému věku a omezené schopnosti srozumitelně artikulovat své potřeby neumí o sebe plnohodnotně postarat. Rodič je tak $v$ obtížné roli pasivního přihližejícího s velkou odpovědností.

Základním přáním rodiče je, aby bylo dítě $v$ MŠ $v$ pořádku (ve smyslu zajištění bezpečí, zdraví, základních fyzických potřeb) a spokojené a aby zde trávilo čas kvalitně (rozvíjelo se, našlo si kamarády, naučilo se nové věci). Rodiče přitom typicky nepřicházejí se strukturovaným seznamem přání a požadavků. Jde spiše o nevyslovená očekávání, $\mathrm{k}$ jejichž jasnému pojmenování dochází často až v okamžiku, kdy realita neodpovídá představě. Informantky $v$ denících zaznamenávají velkou nejistotu ohledně toho, co se $v$ MŠ děje a jak to jejich dítě zvládá, což je zdrojem napětí a psychické nepohody. Věra: „Najednou jsem Vít’u neměla celý den na očích a zároveň jsem nevěděla, jak vlastně bude probíhat jeho adaptace na nové prostředí a kolektiv. Vevnitř mě lehce svírala úzkost.“ (C1)

Aby zmírnily nejistotu a z ní pramenící tenze, snaží se informantky získat zprávy o průběhu dne $v$ MŠ a jeho proživání svými dětmi. Základním zdrojem informací jsou děti, které jsou někdy sdílné, častěji ale nikoliv. Informantky si tak v denících stýskají, že informace od dětí jsou jen velmi omezené, nejasné či zkreslené. Eliška: „Je tedy celé dopoledne pryč a já už nemám možnost sledovat, co tam dělá. Tahám z ní, s kým a s čím si hrála, kolik snědla z oběda a jestli mleli tu mouku, jak je napsáno $v$ programu na nástěnce. Tř́leté dítě ale bohužel ještě není hodnověrný zdroj informací." (C2)

Pokud jasné vyjádření ze strany dětí chybí, snaží se informantky najít nepřímé důkazy o pohodě dítěte $\mathrm{a} v$ denících jsou s úlevou zaznamenána pozorování o tom, jak si dítě hrálo při vyzvedávání, nechtělo z MŠ odcházet, dobře jedlo, odběhlo do tř́dy bez rozloučení apod. Radost a úlevu přináší někdy i jen absence zjevného indikátoru nepohody, tedy že dítě nepláče a neprotestuje. 
Vedle dílčích promluv dítěte a pozorování jeho chování jsou dalším zdrojem informací o pobytu dítěte $v$ MŠ, které zmírňují rodičovskou nejistotu, svědectví od učitelek. Blanka: „Ben se do školky těší. Já jsem spokojená. Při vyzvedávání ho paní Julie chválí, že umí pěkně ríkat $\mathrm{R}$ a že je hodný a samostatný při oblékání apod." (C3)

Informantky kvitují, pokud jsou jim poskytovány, byt' jen banální, informace o pobytu dítěte $v$ MŠ, a naopak vyjadřují zklamání či frustraci, když tyto informace nedostávají. Objevuje se rozhořčení nad nedostatečnou empatií učitelek, které si neuvědomují, co zažívá rodič-nováček a neinformují o dění samy od sebe. $V$ denících se opakují stesky, že na hovor s učitelkou není čas. Některé informantky cítí dotazování jako nepatřičné, nejsou si jisté relevancí svých otázek a vnímají je jako zdržování či obtěžování učitelek zejména s ohledem na vysoký počet dětí ve tř́ídě a nejasné nastavení komunikace. Informantky nechtějí vyčnívat, aby nebyly vnímány jako přehnaně aktivní a potížistky i s ohledem na své dítě (viz C4 a C13). Rozsáhlejší hovor s učitelkami tedy iniciují jen výjimečně, především v případě problémů nebo pro ověření a zpřesnění informace od dítěte. Omezené informace od dětí i od učitelek MŠ jsou doplňovány z dalších zdrojů, např. od jiných rodičů při hovorech $v$ šatně či na hřišti.

Nedostatek informací je nejsilněji a nejčastěji zmiňovanou výtkou informantek směrem k MŠ. Nicméně negativní prožitky jako zklamání nebo naštvání vyvolávají i některé další praktiky, pravidla či reakce MŠ. Objevují se zejména v zápiscích informantek, jejichž děti před nástupem do veřejné $M S ̌$ navštěvovaly nějaké soukromé zařízení péče o dítě (dětská skupina, dětský klub) a jejich představy o fungování jsou tak konkrétnější a založené na př́mé zkušenosti.

Nikola: Nevidím prostor pro flexibilitu, vyjití vstříc individuálním potřebám a zájmům, je to masová záležitost, která jede podle přesně daného řádu a pravidel. Neřeknou ti, co to dítě celý den dělalo, nedostala jsem ani jeden obrázek. Snažím se působit práátelsky a mile, nevyptávat se nějak nepřiměřeně, zbytečně neprudit a přizpůsobit se místním poměrům, aby to třeba nemělo nějaký negativní vliv na to, jak se $k$ Nině chovají. (...) Př́żnačné mi přišlo, že se nás hned ptali, jestli si př́ípadně mưžeme přijít, kdyby bylo dítě nespokojené, kdyby brečelo. Jako kdyby to brali tak, že brečící dítě půjde ze školky pryč a je tady zástup dalších, co rády půjdou na jeho místo. Jako by svưj úkol nevnímali dítě adaptovat, integrovat, ale případně se problémového dítěte zbavit. Možná, že ale na to nemají prostě kapacity. Oproti předchozí školce je to velký rozdíl - nebojují o zákazníka. S Ninou se o školce snažím bavit pozitivně, upevňovat její nadšení a nedávat príliš najevo, že jsem z celé akce školka trochu rozpačitá. (C4)

\subsection{Adaptace rodiče ve vztahu $\mathrm{k}$ adaptaci dítěte}

Pocity rodiče $v$ adaptačním období, jak jsou vyjádřeny $v$ denících, $z$ velké části zrcadlí prožívání události jejich dítětem. Informantky vyjadřují radost, když jsou spokojené jejich děti, a naopak je trápí, když jsou jejich děti v nepohodě. $K$ cíli „spokojené dítě“ směřují různé akce či rozhodnutí zaznamenané v denících, at' už 
68 jde o operativní vyzvednutí z MŠ ve chvíli, kdy dítě pláče, nebo snahu nedat na sobě znát negativní emoce.

Pavlína: V úterý se to obratem mění. Drží se mé nohavice a smutně křičí, že jde se mnou pracovat domů. Je mi hrozně a dělám nic nechápající obličej, jakože to, co oba proživáme, je úplně v pořádku a že není absolutně žádný důvod k tomu, aby byl smutný. Docela mně toto pokrytectví vadí a dost s tím bojuju, obzvláště když vím, že i mně vadí ho tam $v$ tomhle rozpoložení nechat..., ale uvědomuju si, že pokud synovi nedám prostor k tomu, aby vůbec začal smutnit, líp se mi odchází a on tyhle odchody líp nese. (C5)

Adaptace rodiče nicméně není jen pouhým odrazem adaptace dítěte $v$ MŠ. $V$ procesu adaptace rodiče se kromě spokojenosti dítěte vyjednávají také potřeby rodiče jakožto samostatného jedince. Podstatný přitom může být souběh $s$ jinou přechodovou událostí, kterou je třeba návrat do zaměstnání. Zvlášt’ v př́padě, kdy adaptace dítěte $v$ MŠ neprobíhá zcela hladce, je umístění dítěte do MŠ znovu zvažováno, informantky váhají nad frekvencí a délkou odloučení, objevuje se strach ze špatného rozhodnutí a rodičovského selhání.

Dominika: Kdyby to byl deník o mně, rozepsala bych se ted', jak jsem se minulý týden mučila otázkami, zda nejsem krkavčí matka kariéristka (tchyně naznačovala, že jsem). Probírala jsem ze všech stran, jestli třeba opravdu nejsem. Došla jsem k závěru, že by Danovi vůbec neprospělo, kdybych s ním zưstala doma. Visí na mně čím dál víc, doma se nudí a ke všem dětem je vyloženě nepřátelský. Potřebuje kolektiv. A já taky. (C6)

Dalším významným elementem, který do vyjednávání adaptace rodiče vstupuje, je jeho světonázor a představy. Některé informantky nejsou spokojeny s dílčími prvky organizace MŠ, aktivitami nebo výchovnými postupy, pochyby se vážou i na velikost skupiny, striktnost a podobu pravidel či způsob jejich vymáhání, obsah a strukturu činností v MŠ (např. délka pobytu venku, přínos a zábavnost činností) nebo skladbu jídelníčku.

Jitka: Dalo by se to shrnout tak, že se postupně mé naprosté odmítnutí státních školek (kde předpokládám rutinní, nekreativní prístup ve smyslu „hlídání děti“) měnilo do srozumění, že právě tyto školky budou vzhledem k finančním i prostorovým možnostem naší jedinou možností. Pocit viny, že jsem neudělala všechno pro to, abych klukům zajistila dobré vedení, postupem času zeslábl, ale jeho osten nezmizí, myslím, nikdy. (C7)

Vyrovnání se s rozporem mezi představou rodiče a realitou MŠ opět souvisí s průběhem adaptace jeho dítěte. Pokud adaptace dítěte drhne, rozdíly mezi představami rodičů a realitou MŠ se zvýrazňují, rodiče zvažují vhodnost konkrétní MŠ i rozhodnutí zapojení do předškolního vzdělávání (viz dále). Pokud je adaptace dítěte hladká a dítě spokojené a nestrádající, informantky se s kompromisem smiřují snáze a do určité míry si zvnitřňují hodnoty, které reprezentují MŠ. 


\subsection{Požadavky, očekávání a podpora ze strany mateřské školy}

Adaptaci popisujeme jako proces přizpůsobování se požadavkům a očekáváním ze strany MŠ, které směřují k očekávanému cíli, kterým je „dobrý rodič dítěte v MŠ“. Úlohu MŠ nicméně nechceme redukovat pouze na požadavky, protože $v$ deníkových záznamech byla patrná i reflexe podpory ze strany MŠ v procesu adaptace. Ta se přitom může vztahovat jak k přechodové události nástupu dítěte do MŠ, tak k procesu adaptace a zejména k jeho výsledku - začleněnému adaptovanému dítěti.

Př́kladem podpory ze strany $M S ̌$, která reaguje na náročnost přechodové události, je komunikace. Výše jsme uvedly, že informantky typicky nebyly s komunikací ohledně adaptace svých dětí spokojeny (viz C4). Pouze jedna informantka zaznamenala v deníku zkušenost delšího soustředěného rozhovoru s učitelkami nad adaptací své dcery, který nebyl vyvolán bezprostředním problémem. To nicméně neznamená, že by MŠ naprosto selhávaly. Učitelky sice v denících nebyly vykreslovány jako ideální zdroj informací, ale přesto mohly být rozhovory s nimi či rodičovská pozorování jejich práce do značné míry posilující ve zmírňování celkové a mnohovrstevnaté nejistoty, kterou jsme popsaly výše. Považujeme ji proto i za podporu.

Jako specifický druh podpory vnímáme rovněž zapojování rodičů do aktivit MŠ, které může vést $\mathrm{k}$ bližšímu seznámení se a tím i budování důvěry. Ve výsledku tak může ovlivňovat podobu role rodiče. Zapojování rodičů se týkalo typicky dobrovolnických brigád (např. vymalování třídy) nebo manuálních aktivit (šití pytlíčků pro děti, tvořivé dílny apod.).

Irena: $\vee$ tomto týdnu jsme dostali drobné úkoly i my rodiče. To znamená sehnat drobné pomůcky na připravovaný večer tvořivé dílničky, který (...) spočívá v tom, že budou zapojeni (...) i samotní rodiče. Úkoly nejsou samozřejmě povinností, nýbrž záleží na dobré vưli rodičů." (C8)

Intenzivní bylo zapojování informantek z waldorfských MŠ, kde těsně souvisí s jejich filozofií; v jiných MŠ se vyskytovalo řidčeji.

Eliška: Máme první třídní schůzku, vybíráme společně objekt pro školku v přírodě, kam jezdí celé rodiny. Hledají se dobrovolníci na vymalování třídy, plánují se setkání, na kterých by maminky společně vyráběly něco, co se potom prodá na jarmarku a vydělají se tak peníze pro třídu. Vrací se mi nadšení z pospolité atmosféry, která ve školce panuje, a užívám si, že se opět cítím víc vtažená do dění. (C9)

Zatímco pro Elišku je očekávání, že se zapojí do chodu MŠ, radostné a podpưrné, pro Adélu je ambivalentní. Kromě dobrého pocitu z filozofie školy je u ní totiž patrná nejistota, zda mưže očekáváním dostát, protože se netýkají jen „jarmarkư“, ale také relativně silného názoru MŠ na to, že děti mají v tomto věku trávit více času doma, nebo na celkový životní styl. 
Adéla: Na třídní schůzce jsem dostala spoustu domácích úkolů. Rodiče zde berou školku jako projekt, jsou tam přítomní jak tělesně, tak duševně, spoustu věcí dělají svépomocí, s učitelkami si tykají, vtipkují... V principu se mi to líbí, ale zároveň z toho mám trochu strach - nemůžu se jako samoživitelka do toho tolik zapojit, i kdybych chtěla, navíc denně s dojížděním. Maminky téměř výhradně dětem kapsáře a doplňky šijí, spousta z nich je na mateřské se druhým či třetím dítětem, místy si připadám jako exot, že Anička nemá sourozence, aktivního proškolkového tatínka a že já budu muset chodit až na tu pátou (kdy jsou tam ze 75 dětí už jen tak 4-5). (C10)

Co se týče požadavků a očekávání ze strany MŠ, tak velká část z nich má provozně-materiální povahu. Týkají se včasných plateb za služby předškolního vzdělávání, tzv. školkovného a stravného, případně dodání různých dokladů a potvrzení. Dále mezi často zmiňovaný požadavek patří nákup spotřebních materiálů pro třídu, př́ipadně nákup hraček a doplňků. Kromě nákupu nových věcí se objevuje i požadavek na donesení materiálů a pomůcek pro práci dětí ve třídě. Tyto požadavky jsou komunikovány bud' v psané podobě (např. na nástěnce), nebo - častěji - ústní formou (kupř. sdělení při vyzvedávání dítěte, na třídní schůzce). Do provozně-materiálních požadavků ze strany MŠ řadíme i požadavek včasného ranního př́chodu, který je relativně tvrdě vymáhán, př́padně sankcionován.

Lenka: Paní učitelka mě přivítala slovy: „To si snad děláte legraci!“ Velice mě to překvapilo, jedno dítě v náručí, druhý popoháním po schodech nahoru. „Včera jste nebyly a dnes přijdete po půl deváté? Já jsem $s$ vámi už nepočítala, jděte se zeptat do kuchyně, zda vás ještě započítají do jídla." A tak dále, že je to ve školním ráádu, že už nás nemají po půl deváté povinnost přijmout... (C11)

Dalším požadavkem, který relativně častěji ústí v konfliktní situace, je dobrý zdravotní stav dítěte.

Dominika: Hned potom jsem se nepohodla s učitelkou, protože Dan jednou zakašlal. Vyslechla jsem si cosi o nezodpovědných matkách, co z nepochopitelných důvodů nechtějí nechat děti doma. (...) Že je Dan zdravý, nevěřila. Vytočila mě, ale obešlo se to bez hádky. Kvưli Danovi. (C12)

Druhý balík požadavků a očekávání se týká dovedností dítěte, jejichž pomyslným garantem je rodič a očekávání jsou $\mathrm{k}$ němu přímo či nepř́mo směřována (rodič má naučit, zajistit zvládnutí). Těmito dovednostmi může být samoobsluha dítěte, ale i jeho chování. $V$ některých př́padech mohou být tato očekávání sdělována $v$ podobě pochvaly (viz C3), v jiných (když určitá dovednost či chování dítěte nedostačuje - viz C13, C14) vede artikulace těchto očekávání ke kolizím, které se nemusejí odehrát na půdě $M S ̌$, ale které informantky řeší v deníku, jako je tomu v př́padě Lenky: „Jednou jsem Leu vyzvedávala nazlobenou, ani se nechtěla s paní učitelkou rozloučit. Ta mi pak mezi dveřmi řekla, at' s ní doma mluvíme o tom, že se paní učitelka má poslouchat." (C13) 
Z deníkových záznamů se tedy ukazuje, že MŠ poskytují rodičům určitou, byt' velmi omezenou, míru podpory $\mathrm{v}$ jejich náročné situaci. Všechny informantky reflektovaly provozně-materiální požadavky MŠ a některé také požadavky či očekávání vưči dítěti, resp. sobě jako pomyslným garantům dovedností a chování dítěte.

\subsection{Ustavování rodičovské role}

Role rodiče ve vztahu $\mathrm{k} M S S_{\text {se }}$ tedy utváří na pưdorysu starosti o dítě a vypořádávání se s nejistotou a s převážně provozně-materiálními požadavky MŠ, které se s aktuálními potřebami rodiče do značné míry míjejí. Jak dokládá $v$ jednom ze silných úryvků Dominika: „Dan poprvé ráno neplakal, háleluja!:-) Vyzvedávala babička. Vyslechla si sprdunk od obou učitelek, že Dan špatně drží lžíci a pomalu se obléká a svléká. Ale koho to trápí?? On poprvé neplakal!!!“ (C14)

Toto míjení může být samožrejmě méně intenzivní, nicméně to, jak a zda se s ním rodič vypořádá, je pro utváření role zásadní. Dominantní rovinou vztahu rodiče $\mathrm{k} M S ̌$ je starost o adaptaci dítěte a úspěšné zvládnutí nástupu do MŠ coby přechodové události. Rovina rodiče jakožto samostatného individua se dostává ke slovu, když rodič vyhodnocuje pochybnosti týkající se adaptace svého dítěte nebo řeší různé kolizní a problémové situace. Řada rodičů je nicméně ochotna upozadit hodnoty a postoje, poupravit je tak, aby mohly koexistovat s hodnotami MŠ. Zároveň jsou projevy druhé roviny navenek značně regulované a také ne vždy explicitně uvědomované. Nelze zároveň vyloučit, že rovina rodiče jako samostatného individua je významnější např. při výběru MŠ a méně se projevuje $v$ našem datovém souboru, který pokrývá specifický časový úsek.

Pokusíme-li se pak popsat roli rodiče ve vztahu k MŠ, nevyhneme se zachycení základní dynamiky, z niž se role utváríi. Nastavení rodiče je zpočátku velmi zbystřené - rodič má starost o adaptaci dítěte a je připravený spolupracovat, aby adaptace dítěte proběhla úspěšně. Plní proto nároky MŠ a má potřebu o adaptaci dítěte komunikovat, aby o jejím průběhu získal povědomí. Komunikace - kvalita její formy a obsahu - je přitom jednou z podstatných linek vztahu rodiče a vzdělávací instituce.

Pro některé MŠ je př́značné širší spektrum komunikačních kanálů (konzultační hodiny, společné brigády a dílničky) a schopnost rodiče zapojovat se nebo reagovat na jejich nápady. I v těchto MŠ docházelo ke komunikačním šumům, ale zároveň měly informantky relativně více šancí hovořit o svém dítěti v dostatečné míře s učitelkami a zapojovat se do dění v MŠ. Reakce na očekávání spojená s komunitností a souladem rodiče s filozofií MŠ (viz C9 a C10) ukazují úskalí zapojování rodičů, jehož parametry pravděpodobně nikdy nebudou vyhovovat všem rodičům.

Pro jiné MŠ je typické omezené spektrum komunikačních kanálů (hromadná schůzka rodičů, nástěnka), kde je prostor věnován převážně materiálně-provozním záležitostem a $v$ omezené míře dítěti, o kterém rodič může s učitelkou krátce promluvit „mezi dveřmi“ při příchodu či odchodu. MŠ iniciuje intenzivnější komunikaci o dítěti v zásadě jen v př́padě, kdy nastane problém, a to také ne vždy. Přestože toto nastavení není zpočátku pro řadu rodičů vyhovující, tak pokud dítě nemá v MŠ větší 
72 problémy a je $v$ zásadě spokojené, tak se $s$ tímto nastavením rodič postupně smiríi. Pobídky stran zapojování rodičů do MŠ jakožto komunity pak tyto MŠ neformulují, a pokud je vyslovují rodiče, MŠ na ně nejsou připraveny, takže končí spiš rozpačitě.

Monika ve svém deníku např. popisuje, že na rodičovské schůzce byli rodiče vyzváni, aby kromě knih, hraček a papírů na kreslení nakoupili do MŠ také karimatky.

Nabízím, že objednám karimatky hromadně, aby byly všechny stejné a rodiče neměli starost se sháněním. Za pár dní se budu divit. (...) Čekám na objednané karimatky a informuji paní učitelku, kolik je potřeba od rodičů vybrat peněz. Ta mi v klidu odvětí, že čtyři rodiče už donesli karimatky. Cože?! Vidím jmenný seznam, na kterém je nadepsáno KARIMATKY, kam se mají odškrtnout ti, kteří přinesli... CO? Upadám do mdlob. (C15)

Co se týče ustavení role rodiče, jehož dítě nastoupilo do veřejné MŠ, jsou podle nás podstatné následující její charakteristiky. První je zájem o vlastní dítě, o jeho spokojenost, komfort a rozvoj, ale také o úspěšné začlenění. Přestože tomu tak $v$ době nástupu být nemusí, rodič se adaptuje a je adaptován $\mathrm{k}$ tomu, aby ho prostředí MŠ zajímalo jen do té míry, do jaké ovlivňuje jeho dítě. Po linii zájmu vlastního dítěte se také vedou veškerá vyjednávání. Rozvíjení role rodiče ve vztahu k MŠ jako ke komunitě nebo $\mathrm{k}$ vizi MŠ se typicky neděje. Sledování individuálního zájmu zároveň není přímočaré - rodič často zvažuje rizika svého jednání, kdy se nechce „špatně zapsat“, případně kdy má obavy, aby se jeho konflikt neodrazil ve špatném zacházení s jeho dítětem (viz C4, C12, C16, C20).

Druhou charakteristikou a svého druhu strategií je omezená ochota rodiče řešit $s$ MŠ své problémy, resp. problémy, které rodič pocit'uje $v$ souvislosti s nástupem a docházkou do MŠ. Tento rys souvisí s obecným nastavením komunikace. Jen výjimečně měly informantky pocit, že je žádoucí či přijatelné mluvit o svých pochybnostech nebo dílčích kolizích na půdě $M S ̌$ a ještě vzácněji tento prostor měly či si ho vydobyly. Typičtějším jevem bylo „ot’ukáváni“ či krátké, spíše informativně a nekonfrontačně laděné dotazy, případně oznámení konečného rozhodnutí (viz C19, C20). Otevřený rozhovor či konflikt (navzdory emotivně laděným zápisům v denících) není $v$ našem datovém souboru popsán ani jednou; příznačné jsou v tomto ohledu i úryvky C4 a C20, kde je dítě popisované jen s malou nadsázkou jako rukojmí.

Třetí charakteristikou je minimalizace rodičovské iniciativy, a to at' už se týká dítěte, nebo prostředí $M S ̌$. U rodičů, kteří iniciativu v různých směrech projevovali (viz C15), jde o útlum jejich snah, protože se ve většině ukázaly jako nefunkční (výjimkou v našem datasetu je Eliška), př́padně už bylo vyjednáno vše, co rodiče považovali za důležité, anebo důležitost přehodnotili. Nemusí jít přitom nutně o zkušenost daného rodiče, ale o něco, co rodič „odkouká“ na třídní schůzce nebo v šatně či z jiných vrstevnických vztahů.

Kristýna: Prý dostávají odměny [bonbony, pozn. autorek] i za spinkání. Ale co. Prostě je to školkový režim, doma žádné odměny nevedeme. Kdybych se snažila to nějak řešit, tak bych jedině naštvala ostatní rodiče, kteří jsou rádi, že na jejich děti něco platí, anebo by odměny nedostávala jediná Kát'a, a to by asi bylo pro ni složité pochopit. (C16) 
Čtvrtou charakteristikou role rodiče je spolehlivé plnění základních - v podstatě výhradně provozně-materiálních - požadavků ze strany MŠ (včasné příchody a odchody, platby, dodání potvrzení a nákup spotřebního zboží). $V$ některých případech je součástí role rodiče garantování různých dovedností dítěte (samoobslužnost, kázeň), pokud se ukáže, že nedostačují představám MŠ. Rodičovská role je tak ve vztahu k MŠ servisní.

Poslední charakteristikou vztahu je základní uznání prostředí MŠ i s jeho omezeními. Toto uznání je $v$ deníkových záznamech manifestováno typicky jednak pozitivními odkazy na aktivity, které se $v$ MŠ dějí (rozvíjení dovedností dítěte, učení básniček a písniček, kreslení obrázků), jednak pochopením pro složitost podmínek MŠ, které otupuje hroty potřebám rodiče jako v prrípadě Romany: „Trochu mi chybí osobní kontakt s učitelkami - chápu, že při 28 dětech ve třídě nezbývá př́liš prostoru na kontakt s rodiči, ale uvítala bych zpětnou vazbu. “(C17)

Uvedené charakteristiky přitom nejsou vyčerpávajícím výčtem pevných hranic role rodiče. Jde spiše o pomyslné osy, kolem kterých se role rodiče ve vztahu k MŠ buduje bezprostředně po nástupu dítěte do MŠ.

Zmínily jsme, že adaptaci rodiče rozumíme jako stavu, kdy je rodič srozuměn se svou rolí ve vztahu $k M S ̌$ a kdy je naplňování této role přijatelné i pro $M S ̌$. $V$ našem datovém souboru se objevily tři př́pady, kdy se informantky dostaly bud' na hranu této role, resp. ji v dané MŠ nezvládly, nebo roli nechtěly dále plnit.

V prvním př́padě se Monika rozhodla po sérii dílčích kolizí stran stravování, nechození ven, nespaní dítěte a organizace MŠ a zároveň posílena zkušeností dřivější docházky do komunitní lesní školky pro to, aby její dítě kombinovalo docházku do veřejné MŠ s jednodenní docházkou „do lesa“. Lze říci, že role uvedené informantky v principu naplňovala výše uvedené charakteristiky, ale aby je mohla plnit ve veřejné MŠ, cítila potřebu vytvořit si komplementární prostor, kde by byly ve větší míre respektovány její hodnoty a postoje a dostalo se jí a její dceři prožitků, jež oceňuje. Monika se ve svém rozhodnutí opírala jak o svoje vyhodnocení spokojenosti dítěte $\checkmark M S ̌$, tak o své přesvědčení o prostředí prínosném pro její dítě.

Prohližím si nové i staré fotky z lesní školky. Ty nové znalosti, které děti přirozeně získávají. Ty zážitky, ke kterým ve státním skleníku určitě nepřičuchne ani z dálky... Zimní fotky dětí nabalených jak cibule, s rưžovými tvářičkami, nadšené výrazy, jak sjíždí po zadku z hliněného, trošku sněhem poprášeného kopce... A v tu chvíli mi to všechno dochází. Rozdíl, jaké dítě si vyzvedávám z „kamenné školky“ a jaké jsem vyzvedávala $v$ lese. Ošlehané tváře a nadšený výraz, dokonce i ten zmačkaný obrázek kreslený na koleně mi chybí. Co chybí jí, i když to neumí pojmenovat? Dospěla jsem k rozhodnutí vrátit dceru alespoň na jeden den do lesa. (C18)

V druhém př́padě popisovala Dominika zejména prokazatelně neuspokojivý průběh adaptace dítěte, který je pro dynamiku přijetí role rodiče ve vztahu k MŠ kličový (dítě dlouhodobě plakalo $v$ MŠ i doma ze spaní). MŠ navíc projevovala nespokojenost s dovednostmi dítěte (viz C14), ale zároveň nebyla ochotná řešit situaci jinak než poznámkami a dílčími konflikty „mezi dveřmi“, což vedlo ke zpochybňování dané 
74 informantky jako garantky kompetentnosti dítěte. Dominika tak jen stěží mohla MŠ uznávat. Situace vyústila v rozhodnutí změnit veřejnou MŠ za soukromou: „Ráno jsem jedné učitelce řekla o plánovaném přestupu Dana do firemní školky. Odpoledne jsem už měla u druhé připravený papír k podpisu. Nijak to nekomentovaly.“ (C19)

Pro třetí prípad byla příznačná nespokojenost MŠ s dovednostmi dítěte a neochota pracovat se specifiky dítěte. Simona tak neměla př́liš opory pro uznání přístupu MŠ (zástupci MŠ telefonovali Simoně s nátlakem, aby si pro dítě přišla, poznámky o nedostatcích dítěte byly relativně časté) a posléze zajistila přestup do jiné veřejné MŠ: „Ředitelce jen suše sdělím, že se uvolnilo místo v bližší MŠ, a tak přechází Sam jinam. Nemám sílu a odvahu jí sdělovat pravý důvod, aby se ten poslední den nestihla Samovi nějak mstít. Padá mi poměrně velký kámen ze srdce.“ (C20)

$\checkmark$ tomto úryvku jsou pak patrné další charakteristiky role zmiňované výše neochota $\mathrm{k}$ př́mé komunikaci a její úspornost a rovněž starost o dítě jako klíčová hodnota, jíž se podřizují ty ostatní. $V$ prrípadě Dominiky a Simony je pak zřejmé trvání na rodiči jako garantu dovedností dítěte, a to bez jakékoli podpory řešení problémů dítěte ze strany MŠ.

\section{Diskuse}

Z našich dat vyplývá, že rodiče se $s$ adaptací a hledáním své role musí vypořádávat vesměs sami. Zatímco Markströmová a Simonssonová (2017, s. 187) ukazují, jak švédští pedagogové $v$ průběhu adaptačního období cíleně socializují rodiče do role aktivních, flexibilních a samoregulujících se partnerů, české $M S ̌$ takto aktivní nejsou (výjimku v našich datech představují dvě waldorfské MŠ). Přímo o představách a záměrech $M S ̌$ naše data nic neř́kají ( $\mathrm{v}$ tomto ohledu by si naše $z$ definice jednostranná stat’ zasloužila „zrcadlo“ $v$ podobě studie vnímání adaptačních procesů dítěte a rodiče ze strany $M S ̌$ ), ale můžeme $z$ nich vyvozovat minimálně to, že naše informantky takové snahy od MŠ nezaznamenávají.

Socializace rodičů ze strany MŠ je tedy pravděpodobně spís implicitní, nicméně velká část našich informantek se relativně rychle adaptovala do role spíše pasivní, nepř́liš nápadné a servisní, v níž lze možná spatřit počátek „tichého partnerstvi“, jak jej zachytila Šed'ová (2009). I naše informantky, které zastupují stejnou (tj. střední) společenskou vrstvu jako u Šed'ové, reflektují nároky MŠ ohledně materiálního zajištění dětí a plnění provozních požadavků a často též implicitní očekávání zdrženlivé komunikace. Rodič má být připraven vyslechnout učitelku a reagovat na její výzvy, ale sám delší komunikaci iniciuje jen v případě vážného problému.

Pro naše informantky není přijetí role „tichého partnera“ vždy zcela bezbolestné, i když je nakonec velkou částí z nich podobná role akceptována. Není tomu však u všech a je zajímavé porovnat tyto prípady s evidencí Pulišové (2016) o „problematických" rodičích na úrovni základní školy. Vzhledem ke skladbě našich informantek ( $v$ našem souboru jsou jen rodiče, kteří mají kapacitu a chut' věnovat čas reflexi prvních týdnů $v$ MŠ) není př́liš překvapivé, že se mezi nimi nevyskytl prípad 
nespolupracujícího, pasivního rodiče, který by nebyl schopen dostát očekáváním na tichou spolupráci. Objevují se však rysy nespokojenosti, které Pulišová identifikuje jako další typy problémového jednání rodičů vzhledem ke škole. Zajímavé je, že hlasitá nespokojenost a boj se školou se u našich informantek objevuje jen v náznacích a poměrně rychle se transformuje do nespokojenosti tiché, která vyústí bud' $\checkmark$ rezignaci a smírení, anebo k přestupu do jiné MŠ. To se děje bez většího vysvětlení důvodů (viz C19, C20), což koresponduje s jednáním tiše nespokojených rodičů zachycených Pulišovou. Otázkou tedy je, proč naše informantky oproti těm z výzkumu Pulišové, své výhrady hlasitě nevyjadřují, s mateřskou školou nebojují. Mưžeme jen spekulovat, zda je to dáno naším zaměřením na období adaptace, kdy si informantky ještě nejsou jisté svou pozicí, nebo snad rozdílným charakterem a vnímáním role předškolního a základního vzdělávání, kde jsou jinak nastaveny povinnosti a práva a z nich plynoucí nároky a očekávání.

V této souvislosti může pomoci studie Vuorinenové (2018), která se stejně jako my soustředila na předškolní stupeň vzdělávání. Identifikuje čtyři rodičovské přístupy: (a) oceňování MŠ; (b) přijetí situace v MŠ, i když není vše zcela dle představ rodičů; (c) snahu o změnu situace $v$ MŠ; (d) přestup do jiné $M S ̌$. V našich datech se v nějaké míře objevují všechny čtyři přístupy, nicméně nejslabší evidenci máme o třetím $z$ nich (snaze o změny $v$ rámci instituce), který částečně koresponduje právě s hlasitou nespokojeností dle Pulišové (2016), i když má neutrálnější konotaci. Ten se, jak již bylo řečeno, u žádné z našich informantek nevyskytuje osamoceně, ale jeho náznak lze najít např. u informantky Moniky (viz C15), kde však velmi záhy dochází ke změně přístupu na smířlivě-rezignovaný nebo tiše-odmítavý. Vuorinenová (2018) nicméně popisuje větší rozmanitost a menší přímočarost rodičovských drah, než se ukázaly $v$ našich datech. Rozsáhlejší závěry ohledně rozdílů ale nelze činit, nebot' výzkumy měly jiné cíle i designy a mezinárodní srovnávání v oblasti péče o děti předškolního věku je ošemetné i tím, že terén je značné nesourodý (liší se typ institucí, věk nástupu dětí, velikost skupiny, míra účasti rodin apod.).

Slabé zastoupení, resp. omezená doba trvání aktivně-reformního rodičovského přístupu $v$ našich datech, nás provokuje $k$ dalším úvahám. Může se samozřejmě jednat pouze o důsledek časového omezení našich dat, která se zaměřují jen na první týdny po nástupu a nezachycují ani dobu předcházející (výběr MŠ), ani následnou. Nicméně skutečnost, že náznaky tohoto přístupu se v datech vyskytují, ale jsou poměrně záhy utlumeny, nás vede $k$ formulaci hypotézy, že část dưvodů leží i v nastavení samotných MŠ, které na podobný přístup rodičů oproti těm švédským vesměs nejsou připraveny, na což ostatně upozorňují ve svých textech i Majerčíková (2015), Pulišová (2016) a Štech (2004). MŠ často neumí (nebo nechtějí) nastavit vztahy tak, aby se rodiče cítili ve svých aktivitách podpořeni. I naše data přitom ukazují, že středostavovští rodiče vstupují do MŠ s vysokým zájmem o dění v ní, ochotou zapojit se a spolupracovat na rozvoji MŠ (srov. Majerčíková, 2015). Pokud projeví iniciativu, vnímají mnohdy odezvu MŠ jako zdrženlivou, nebo odmítavou, což je záhy vede ke stažení se. Odmítavá reakce MŠ je přitom někdy jen předjímána a aktivita nad rámec nastavených pravidel je rodiči zavrhována dřive, než je vyzkoušena. 
Adaptaci rodiče jsme popsaly jako proces, který má několik charakteristik:

Předně vzniká v reakci na přechodovou událost nástupu dítěte do MŠ. Ten je rodinnou přechodovou událostí (Niesel \& Griebel, 2005) a adaptace na ni čeká jak dítě, tak jeho rodiče. Rodičovské zápisky našich informantek jsou plné emocí a mezi popisovanými prožitky najdeme i řadu nepř́jemných, jakými jsou nejistota, úzkost, napětí, naštvání či zklamání. To potvrzuje, že nástup do MŠ je emocionálně náročný pro všechny zúčastněné, jak konstatují Markströmová a Simonssonová (2017), které upozorňují na rodičovskou nejistotu ohledně toho, jaký má být „dobrý rodič dítěte $\checkmark M S ̌ “$ “, a upozorňují rovněž na to, že předat a opustit dítě může být podobně zátěžové jako být opuštěn rodičem.

Dalším podstatným rysem je, že adaptace rodiče je těsně svázána s adaptací dítěte (srov. např. Majerčíková, 2015). Klíčovými parametry toho, jak rodič adaptaci prožívá, jsou spokojenost jeho dítěte a podoba jeho adaptace. Zároveň nelze adaptaci rodiče jednoduše odvozovat od adaptace dítěte. Přestože dítě mưže nástup do MŠ proživat bez větších problémů, adaptace rodiče mưže být náročná a - jak budeme argumentovat dále - je žádoucí vnímat ji do značné míry jako proces, který si zaslouží samostatnou pozornost.

Konečně je adaptace rodiče podstatným a neprávem přehlíženým tématem také proto, že se $v$ jejím průběhu vyjednává a ustavuje role rodiče školkového dítěte a vztah rodiče $k$ MŠ. Konkrétní podoba tohoto vztahu a role je pochopitelně souhrou mnoha proměnných - osobnosti dítěte, osobnosti rodiče, zkušeností, dostupností alternativ, učitelek, MŠ, vědomého uchopení tématu adaptace apod. Za důležité nicméně považujeme, že at' už je adaptace rodiče řízená, či alespoň moderovaná (Markström \& Simonsson, 2017), nebo probíhá spiše „samospádem“ jako u většiny našich informantek, vždy je jejím výsledkem nějak ustavená role a vztah k MŠ, které maji své důsledky. To, že je v Česku zájem o adaptaci rodiče mizivý, je krátkozraké hned $v$ několika ohledech.

Jednak se tím může komplikovat adaptace dítěte. Spolupráce rodiče a školy je jedním z předpokladů dobré dětské adaptace (OECD, 2017, s. 21). Nejde přitom jen o krátkodobý zájem o hladké začlenění dítěte do konkrétní MŠ, ale i o dlouhodobější perspektivu, kdy zpưsob zvládnutí jednoho přechodu ovlivňuje zvládání těch dalších, tedy např. nástup do základní školy (Helus, 2014; Vágnerová, 2012).

Dále je nezájem o adaptaci v př́krém rozporu s proklamovaným úsilím o partnerství, jež je deklarováno zejména ve veřejněpolitických dokumentech (např. Čšl, 2020; MŠMT, 2014, 2018) či popisováno v odborné literatuře (např. Rabušicová et al., 2004; Syslová, 2013; Šed’ová, 2009). Určit povahu vztahu hned na začátku je totiž nepoměrně jednodušší než se jej snažit později redefinovat.

Třetím důvodem, proč je důležité zabývat se adaptací rodiče, je posílení sociální soudržnosti ve společnosti a dưvěry vưči systému. $Z$ našich dat totiž adaptace rodiče po nástupu dítěte do MŠ vypadá náročně i pro středostavovské a motivované informantky a je pravděpodobné, že pro některé jiné skupiny $s$ nižším 
sociálně-ekonomickým statusem je ještě obtížnější. Rodič jako zákonný zástupce dítěte má velký prrímý i nepř́mý vliv na studijní trajektorii svého dítěte, a pokud se mu nepodaří navázat k systému vztah důvěry, nemusí mít do budoucna dostatek kapacit pro řešení problémů, se kterými se jeho dítě setká (Greger et al., 2015). Z hlediska sociální soudržnosti pak není zcela podstatné, jestli rodič dítě přehlásí do soukromé školy nebo jestli ho do školy přestane posílat úplně.

Představená zjištění a navazující úvahy nás vedou $\mathrm{k}$ formulaci několika výzkumných úloh, které by dle našeho názoru stály za budoucí výzkum: 1) Adaptaci rodiče a ustanovování jeho role zkoumáme jen z perspektivy samotných rodičů. Tento pohled by bylo vhodné doplnit perspektivou druhé strany, tedy pedagogů a vedení mateřských škol. 2) Náš výzkum se soustředí na období adaptace a ukazuje ustanovování rodičovské role. Tato role a vztah rodiče a MŠ se však mohou měnit a mění i později. Další badatelskou úlohu tedy představuje dlouhodobější sledování dynamiky vztahu rodiny a školy, a to nejen mateřské, ale i později základní. 3) Sběr dat jsme zahájily až nástupem dítěte do $M S ̌$ a nezachycujeme období výběru mateřské školy. To je bezpochyby důležité pro tvorbu očekávání rodičů od MŠ a promítá se do vztahu mezi MŠ a rodičem. 4) Rozdílnost přístupů rodičů $z$ našeho výzkumu a $z$ výzkumu Pulišové (2016) na základní škole ukazuje na potřebu popsat odlišnosti ve vnímání rodičovské role na různých stupních škol. 5) $V$ naší stati mapujeme proces adaptace rodiče a jeho roli po skončení této adaptace, kde je souvislost mezi adaptací a rolí, k niž rodič dospěje, relativně těsná. Zajímavé by nicméně bylo zkoumat i další trajektorie těchto rodičů, aby se jasněji vyjevilo, jaký vliv má adaptace na roli rodiče $\checkmark$ dlouhodobé perspektivě. 6) Náš výzkum se věnuje specifické skupině rodičů, a to matkám ze středních vrstev. Bylo by prrínosné zaměřit výzkumnou pozornost i na další skupiny, jednak na otce, ale především na jiné společenské vrstvy.

Nevylučujeme, že se $v$ časovém odstupu pěti let, která uběhla mezi sběrem dat a publikací jejich analýzy, udály $v$ dané oblasti posuny. Zároveň nemáme až na drobné výjimky žádná svědectví o vědomém uchopování tématu adaptace rodiče. Doufáme proto, že se adaptace rodiče postupně stane tématem jak pro MŠ, tak pro tvůrce metodických a strategických dokumentů a pro akademiky. Ve společné diskusi bude potřeba pečlivě a citlivě - bez jednoduchého označování viníků na obou stranách - zkoumat, jaké vztahy mezi rodiči a školou aktuálně panují, zda a proč nám vyhovují, jaké mají zdroje a zejména, jaké spektrum vztahů a rolí chceme a jsme připraveni mít a utvářet.

\section{Poděkování}

Práce Kateřiny Konrádové na tomto článku byla podpořena v rámci projektu Specifického vysokoškolského výzkumu - 260 596, práce Evy M. Hejzlarové a Magdaleny Mouralové na tomto článku pak byla podpořena v rámci programu Progres Univerzity Karlovy Q18 - Společenské vědy: od víceoborovosti k mezioborovosti. 
Alasuutari, M. (2010). Striving at partnership: Parent-practitioner relationships in Finnish early educators' talk. European Early Childhood Education Research Journal, 18(2), 149-161. https://doi.org/10.1080/13502931003784545

Alaszewski, A. (2006). Using diaries for social research. London: SAGE.

Burkovičová, R. (2018). Attitude of children's parents, teachers, and headmasters towards the admission of two-year-olds to kindergartens in the Czech Republic. Pedagogika Przedszkolna i Wczesnoszkolna, 6, 223-232.

ČŠl. (2020). Kritéria hodnocení podmínek, průběhu a výsledků vzdělávání na školní rok 2020/2021. Česká školní inspekce. https://www.csicr.cz/Csicr/media/Prilohy/PDF_el. _publikace/Krit\%c3\%a9ria/Kriteria-hodnoceni_2020-2021-popis-kriteria_cistopis.pdf

Eisenhower, A., Taylor, H., \& Baker, B. L. (2016). Starting strong: A school-based indicated prevention program during the transition to kindergarten. School Psychology Review, 45(2), 141-170. https: / /doi.org/10.17105/SPR45-2.141-170

Eurydice. (2017). Česká republika: Organizace péče o děti do 2-3 let. https: / /eacea.ec.europa .eu/national-policies/eurydice/content/organisation-programmes-children-under-2-3 -years-9_cs

Fails Nelson, R. (2004). The transition to kindergarten. Early Childhood Education Journal, 32(3), 187-190. https://doi.org/10.1023/B:ECEJ.0000048971.21662.01

Goshen, O. (2016). Collaboration between parents and kindergarten teachers. Studia Edukacyjne, (39), 497-509. https://doi.org/10.14746/se.2016.39.27

Greger, D., Simonová, J., \& Straková, J. (Eds.). (2015). Spravedlivý start? Nerovné šance $v$ předškolním vzdělávání a při přechodu na základní školu. Praha: PedF UK.

Hanafin, J., \& Lynch, A. (2002). Peripheral voices: Parental involvement, social class, and educational disadvantage. British Journal of Sociology of Education, 23(1), 35-49. https: // doi.org/10.1080/01425690120102845

Hašková, H., Saxonberg, S., \& Mudrák, J. (2012). Péče o nejmenší: Boření mýtů. Praha: Sociologické nakladatelství (SLON) v koedici se Sociologickým ústavem AV ČR.

Havlík, R., \& Kot’a, J. (2007). Sociologie výchovy a školy. Praha: Portál.

Heckman, J. J., Moon, S. H., Pinto, R., Savelyev, P. A., \& Yavitz, A. (2010). The rate of return to the HighScope Perry Preschool Program. Journal of Public Economics, 94(1-2), 114-128. https: / /doi.org/10.1016/j.jpubeco.2009.11.001

Hedlin, M. (2019). 'They only see their own child': An interview study of preschool teachers' perceptions about parents. Early Child Development and Care, 189(11), 1776-1785. https: // doi.org/10.1080/03004430.2017.1412955

Helus, Z. (2014). K psychologii láskyplného vztahu: Pedagogické inspirace se zaměřením na předškolní výchovu. Pedagogická orientace, 24(4), 468-487. https://doi.org/10.5817 /PedOr2014-4-468

Hornby, G., \& Lafaele, R. (2011). Barriers to parental involvement in education: An explanatory model. Educational Review, 63(1), 37-52. https://doi.org/10.1080/00131911.2010 .488049

Chan, W. L. (2012). Expectations for the transition from kindergarten to primary school amongst teachers, parents and children. Early Child Development and Care, 182(5), 639-664. https://doi.org/10.1080/03004430.2011.569543

Karila, K. (2012). A Nordic perspective on early childhood education and care policy. European Journal of Education, 47(4), 584-595. https://doi.org/10.1111/ejed.12007

Karlsson, M., \& Perälä-Littunen, S. (2017). Managing the gap - policy and practice of parents in child care and education. Nordic Journal of Studies in Educational Policy, 3(2), 119-122. https: / /doi.org/10.1080/20020317.2017.1389137

Katrňák, T. (2004). Odsouzeni k manuální práci: Vzdělaností reprodukce $v$ dělnické rodině. Praha: Sociologické nakladatelství (SLON). 
Konrádová, K. (2017). Předškolní vzdělávání: Vztahy mezi mateřskou školou a rodinou [Diplomová práce, Univerzita Karlova]. Digitální repozitář UK. https://dspace.cuni.cz/handle /20.500.11956/87072

Kot'átková, S. (2014). Dítě a mateřská škola: Co by měli rodiče znát, učitelé respektovat a rozvíjet. Praha: Grada.

Kropáčková, J., \& Janík, T. (Eds.). (2014). Předškolní pedagogika - etablování oboru [Monotematické číslo]. Pedagogická orientace, 24(4). https://journals.muni.cz/pedor/issue /view/180

Lietavcová, M., Vítečková, M., \& Jošt, J. (2018). Child transition from kindergarten to primary school as experienced by a kindergarten teacher. ICERI2018 Conference Proceedings, 3885-3890. https://doi.org/10.21125/iceri.2018.1866

Majerčíková, J. (2011). Rodina a jej dôvera k škole. Pedagogika.sk, 2(1), 9-27.

Majerčíková, J. (2015). Sporné aspekty úzkych vzt’ahov rodiny a školy na začiatku vzdelávania. Studia paedagogica, 20(1), 29-44. https://doi.org/10.5817/SP2015-1-3

Majerčíková, J., \& Rebendová, A. (2016). University kindergarten: The story of a little big school. Acta Technologica Dubnicae, 6(3), 83-99. https://doi.org/10.1515/atd-2016-0021

Månsson, A. (2011). Becoming a preschool child: Subjectification in toddlers during their introduction to preschool, from a gender perspective. International Journal of Early Childhood, 43(1), 7-22. https://doi.org/10.1007/s13158-010-0022-6

Markström, A.-M. (2010). Talking about children's resistance to the institutional order and teachers in preschool. Journal of Early Childhood Research, 8(3), 303-314. https://doi .org/10.1177/1476718X10368591

Markström, A.-M., \& Simonsson, M. (2017). Introduction to preschool: Strategies for managing the gap between home and preschool. Nordic Journal of Studies in Educational Policy, 3(2), 179-188. https://doi.org/10.1080/20020317.2017.1337464

Matějů, P., Straková, J., \& Veselý, A. (Eds.). (2010). Nerovnosti ve vzdělávání: Od měření $k$ řešení. Praha: Sociologické nakladatelství (SLON).

McIntyre, L. L., Eckert, T. L., Fiese, B. H., DiGennaro, F. D., \& Wildenger, L. K. (2007). Transition to kindergarten: Family experiences and involvement. Early Childhood Education Journal, 35(1), 83-88. https://doi.org/10.1007/s10643-007-0175-6

Melhuish, E., Ereky-Stevens, K., Petrogiannis, K., Ariescu, A., Penderi, E., Rentzou, K., ... Leseman, P. (2015). A review of research on the effects of Early Childhood Education and Care (ECEC) upon child development. EU CARE project. Utrecht University Repository. https:// www.researchgate.net/publication/291970194_A_review_of_research_on_the_effects_of _early_childhood_Education_and_Care_ECEC_upon_child_development_CARE_project

MŠMT. (2014). Strategie vzdělávací politiky České republiky do roku 2020. Praha: Ministerstvo školství, mládeže a tělovýchovy České republiky. http://www.vzdelavani2020.cz/images obsah/dokumenty/strategie-2020_web.pdf

MŠMT. (2018). Rámcový vzdělávací program pro předškolní vzdělávání. Praha: Ministerstvo školství, mládeže a tělovýchovy České republiky. https://www.msmt.cz/file/45304/

MŠMT. (2020). Výroční zpráva o stavu a rozvoji vzdělávání v České republice v roce 2019. Praha: Ministerstvo školství, mládeže a tělovýchovy České republiky. https: / /www.msmt .cz/vzdelavani/skolstvi-v-cr/statistika-skolstvi/vyrocni-zpravy-o-stavu-a-rozvoji-vzdelavani -v-ceske-1

Niesel, R., \& Griebel, W. (2005). Transition competence and resiliency in educational institutions. International Journal of Transitions in Childhood, 1. https://extranet.education .unimelb.edu.au/LED/tec/pdf/journal_niesel_griebel.pdf

Noel, G. M. (2008). Mother and teacher interaction in preschools during parent-teacher conferences [Doctoral thesis, Indiana University of Pennsylvania]. IUP, United States. http: // citeseerx.ist.psu.edu/viewdoc/download;jsessionid=45723CACE7C265B8D8A4DAC2EAD 9D9A5?doi=10.1.1.940.4060\&rep=rep1\&type=pdf

OECD. (2017). Starting strong 2017: Key OECD indicators on early childhood education and care. Paris: OECD Publishing. 
80 OECD. (2018). OECD Family Database. http://www.oecd.org/els/family/database.htm\#public policy

Pecháčková, Y. (2014). Spolupráce školy a rodiny se zaměřením na vzájemná očekávání [Disertační práce, Univerzita Karlova]. Digitální repozitář UK. https://dspace.cuni.cz/handle /20.500.11956/68977

Pelikánová, I. (2018). Spolupráce školy a rodiny v různých typech předškolních zařízení [Diplomová práce, Univerzita Tomáše Bati ve Zlíně]. Elektronický archiv knihovny UTB. http:// hdl.handle.net/10563/42858

Petriwskyj, A., Thorpe, K. \& Tayler, C. (2005). Trends in construction of transition to school in three western regions, 1990-2004. International Journal of Early Years Education, 13(1), 55-69. https: / / doi.org/10.1080/09669760500048360

Prokop, D. (2019). O školkách a dětech. In D. Prokop, Slepé skvrny: O chudobě, vzdělávání, populismu a dalších výzvách české společnosti (s. 83-90). Brno: Host.

Prokop, D., \& Dvořák, T. (2019). Analýza výzev vzdělávání v České republice. Nadační fond Eduzměna. https://eduzmena.cz/wp-content/uploads/2019/05/Eduzme\%CC\%8Cna_A4 Studie-celek_III.pdf

Provázková Stolinská, D., \& Rašková, M. (2015). Reflection of paradigms of relationships between family and school in the Czech Republic. SGEM2015 Conference Proceedings (kniha 1 , svazek 2, s. 805-810). https://sgemsocial.org/ssgemlib/spip.php?article1460

Pulišová, K. (2016). Neklape nám to: Učitelé a rodiče žáků prvního stupně základních škol a jejich problémové vztahy. Studia paedagogica, 21(3), 167-182. https://doi.org/10.5817 /SP2016-3-9

Rabušicová, M. (2004). Postavení rodičů jako výchovných a sociálních partnerů školy (shrnutí některých výsledků z výzkumného projektu). Pedagogika, 54(4), 326-341.

Rabušicová, M., Čiháček, V., Emmerová, K., \& Šed’ová, K. (2003). Role rodičů ve vztahu ke škole - empirická zjištění. Pedagogika, 53(3), 309-320.

Rabušicová, M. , \& Emmerová, K. (2003). Role rodičů ve vztahu ke škole - teoretické koncepty. Pedagogika, 53(2), 141-151.

Rabušicová, M., Šed'ová, K., Trnková, K., \& Čiháček, V. (2004). Škola a (versus) rodina. Brno: MU.

Rimm-Kaufman, S. E., Pianta, R. C., \& Cox, M. J. (2000). Teachers' judgments of problems in the transition to kindergarten. Early Childhood Research Quarterly, 15(2), 147-166. https://doi.org/10.1016/S0885-2006(00)00049-1

Rous, B., Hallam, R., McCormick, K., \& Cox, M. (2010). Practices that support the transition to public preschool programs: Results from a National Survey. Early Childhood Research Quarterly, 25(1), 17-32. https://doi.org/10.1016/j.ecresq.2009.09.001

Simonová, J. (2017). Charakteristiky dobré základní školy z pohledu rodičů. Pedagogická orientace, 27(1), 136-159. https://doi.org/10.5817/PedOr2017-1-136

Simonová, J., Potužníková, E., \& Straková, J. (2017). Poslání a aktuální problémy předškolního vzdělávání - postoje a názory ředitelek mateřských škol. Orbis scholae, 11(1), 71-91. https: / /doi.org/10.14712/23363177.2017.18

Simonsson, M. (2018). Changing subject positions of the parents during the introduction to the Swedish preschool. In Proceedings of Sixteenth Annual Hawaii International Conference on Education (sv. 1, s. 153-153). http: //urn.kb.se/resolve?urn=urn:nbn:se:liu:diva-144212

Straková, J., \& Simonová, J. (Eds.). (2017). Předškolní vzdělávání a přechod do základní školy [Monotematické číslo]. Orbis scholae, 11(1). https://doi.org/10.14712/23363177.2017.15

Syslová, Z. (2013). Profesní kompetence učitele mateřské školy. Praha: Grada Publishing.

Syslová, Z., \& Najvarová, V. (2012). Předškolní vzdělávání v České republice pohledem pedagogického výzkumu. Pedagogická orientace, 22(4), 490-515. https://doi.org/10.5817/ PedOr2012-4-490

Šed'ová, K. (2009). Tiché partnerství: Vztahy mezi rodiči a učitelkami na prvním stupni základní školy. Studia paedagogica, 14(1), 27-52.

Šmelová, E. (2005). Předškolní vzdělávání očima rodičovské veřejnosti. Pedagogická orientace, 15(1), 52-57.

Štech, S. (2004). Angažovanost rodičů ve školní socializaci dětí. Pedagogika, 54(4), 374-388. 
Šulová, L. (2016). Nástup dítěte do školy jako významný vývojový mezník. Psychologie pro praxi, 51(3-4), 71-84.

Trnková, K., \& Čiháček, V. (2003). Možnosti prosazování zájmů rodičů ve škole. Pedagogická orientace, 13(2), 22-37.

Vágnerová, M. (2012). Vývojová psychologie: Dětství a dospívání. Praha: Karolinum.

Van Laere, K., Van Houtte, M., \& Vandenbroeck, M. (2018). Would it really matter? The democratic and caring deficit in 'parental involvement'. European Early Childhood Education Research Journal, 26(2), 187-200. https://doi.org/10.1080/1350293X.2018.1441999

Viktorová, I. (2020). Jak učitelé vnímají komunikaci s rodiči: Spokojení vs. vyhořelí. Pedagogika, 70(1), 29-42. https://doi.org/10.14712/23362189.2019.1343

Viktorová, I., \& Štech, S. (2010). Vztahy rodiny a školy - hledání dialogu. In Z. Kolláriková \& B. Pupala, Předškolní a primární pedagogika: Predškolská a elementárna pedagogika (s. 57-94). Praha: Portál.

Vogler, P., Crivello, G., \& Woodhead, M. (2008). Early childhood transitions research: A review of concepts, theory, and practice. The Hague: Bernard van Leer Foundation.

Vuorinen, T. (2018). 'Remote parenting': Parents' perspectives on, and experiences of, home and preschool collaboration. European Early Childhood Education Research Journal, 26(2), 201-211. https://doi.org/10.1080/1350293X.2018.1442005

Vyroubalová, I. (2015). Adaptace dětí na mateřskou školu jako proces předcházení zátěžovým situacím [Bakalářská práce, Masarykova univerzita]. Informační systém MU. https:// is.muni.cz/th/yj7a5/

Yngvesson, T., \& Garvis, S. (2019). Preschool and home partnerships in Sweden, what do the children say? Early Child Development and Care [on-line]. https://doi.org/10.1080/0300 4430.2019.1673385

Mgr. Eva M. Hejzlarová, Ph.D., katedra veřejné a sociální politiky Fakulta sociálních věd, Univerzita Karlova Pekařská 641/16, 15500 Praha 5 - Jinonice eva.hejzlarova@fsv.cuni.cz

Mgr. Magdalena Mouralová, Ph.D., katedra veřejné a sociální politiky Fakulta sociálních věd, Univerzita Karlova Pekařská 641/16, 15500 Praha 5 - Jinonice magdalena.mouralova@fsv.cuni.cz

Mgr. Kateřina Konrádová, katedra veřejné a sociální politiky Fakulta sociálních věd, Univerzita Karlova Pekařská 641/16, 15500 Praha 5 - Jinonice katerina.konradova@fsv.cuni.cz 